\title{
宿題報告
}

\section{2. コレステロール胆石の成因と臨床}

\section{梶山 梧朗}

Key words：コレステロール胆石，胆汁脂質粒子，ウルソデオキシコール酸，腹腔鏡下胆霊摘出術

\section{はじめに}

胆石はわが国で戦後50数年の間に著明な増加 を来した疾患の一つであることは周知の通りで ある。また増加したものの大部分はコレステ ロール胆石であり，その傾向は胆䨓結石で著し いことも数年前実施された全国調查でも確認さ れている゙.

このような戦後の社会状勢の回復と期を一に して著増した病気には, 肥満, 高脂血症（高中 性脂肪血症), 糖尿病, 虚血性心疾患などが広 く知られており，これらの原因はいずれも高力 ロリーを始めとする食生活の変化によるものと 考えられている．従ってこうした患者の多くは 生活習慣病と称し, 古くから食生活の是正を中 心とした予防概念が浸透してきたことも周知の 通りである。しかし，わが国では何故か胆石の みに対してはこうした予防に対する考えは希薄 のまま今日に至っていることも事実である.

言うまでもなく高頻度にコレステロール胆石 の発生をみる欧米では胆石予防に対する考えは わが国のそれよりは遥かに古くより受け入れら れており 2,3)，色素石主体であった歴史をむつ わが国ではこうした考えに遅れをとってきた可 能性が高い。
われわれの教室では長年に亘り胆石, とくに コレステロール胆石の発生や消失過程において 起こる胆汁成分の変化を観察し, そのメカニズ 厶を探るなかで，胆石の治療，更には予防につ いても検討してきた.

胆軎結石のうち，すでに述べたように，その 多くがコレステロール結石で占められているこ とが明らかでありながら, 最近のその治療法は 腹腔鏡的胆慗切除術が大勢を占めていることは 万人の認めるところである．そこで，わが教室 では関連施設の内科抢よび外科と協力して，本 法がスタートして以来約10年間の患者の経過を 钼察してきた。本法による腹壁の切開創が従来 採られてきた開腹によるそれとは較べものにな らない程小さいために, 術直後の回復が早いこ とが本法の最大の利点とされてきた。また手術 技術の進歩, 術前術中検查法の進歩により, 遺 残結石も少なくなり, 胆霊摘出後症候群, つま $り$ ，胆䧶摘出後の残りの胆道系の障害に基づく 訴えが激減していることは事実である。しかし 腹腔鏡的胆䨳摘出術が開始されてから, 約 10 年 に及ぶ経過のなかで患者にとって15\%前後の術 前とは異なる新たな訴え（心裔部, 背部, 下腹 部など術前と似ているが感覚的に異なる訴えま たは異なる部位に新たに感じる症状）が出現し ており，これは開腹手術後にみられた訴えの頻 度と概略大差はみられなかった $。$

われわれはこの $15 \%$ 程度の新たな症状につい 
1）過飽和胆汁の形成

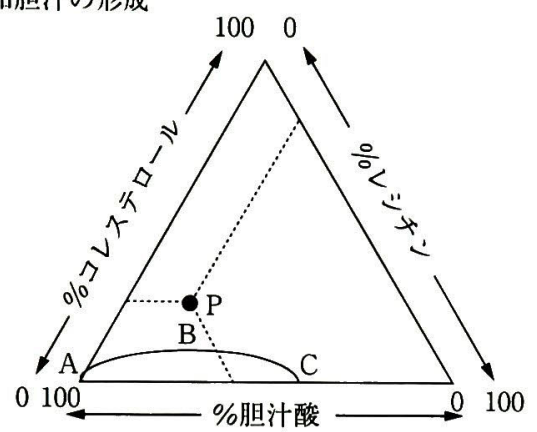

2）コレステロール結晶形成（Nucleation）のおこりやすさ $\lceil$ NUCLEATION TIME $\square$
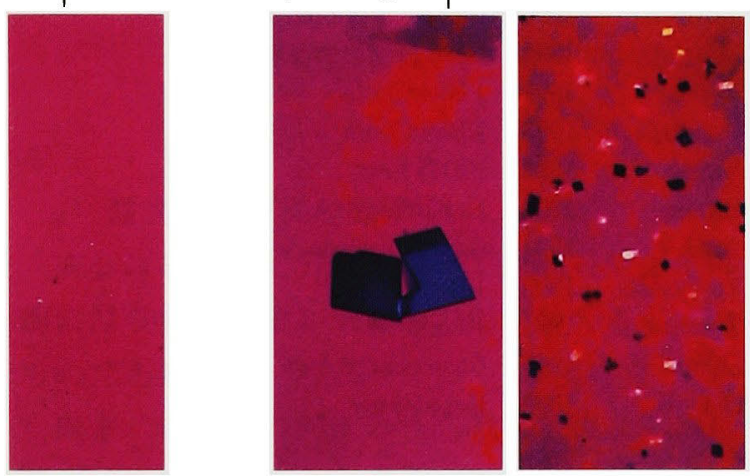

胆汁中に析出したコレステロール結晶

結晶ができるまでの時間 = nucleation time（=おこり やすさ)

nucleation time：長い 起こりにくい

短い 起こりやすい

図1.コレステロール胆石ができるための2つのス テップ

て分析し，その発生メカニズムについて検討し たところ，その原因の大きな部分を占めると思 われるものは従来言われていた，いわゆる胆霬 摘出後症候群ではなく, 胆襄が摘出されること に伴って起こってくる幽門の機能不全による胆 汁の胃内逆流に基づいた異常であることを明ら かにすることができた5).

これらのことからわれわれはできるだけ胆霊 を温存するためにA. コレステロール胆石の生 成過程を明らかにすることを通して, 従来の胆 石の内科的治療より一歩進んで発生予防につい て言及した．更にB. 胆囊を失うことによって 長い経過中に起こり得る胃病変についてその病

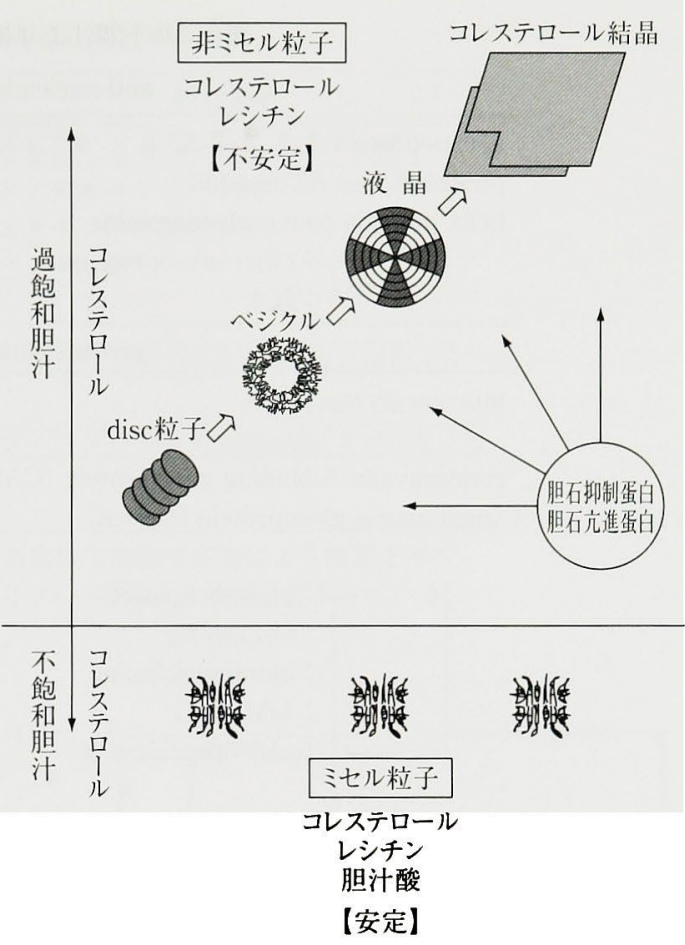

図 2. 胆汁脂啠粒子からコレステロール結晶化への 流れ

態と発生メカニズムとその予防法について研究 した。

\section{1.コレステロール胆石生成機構とその} 発生，および抑制因子 ${ }^{6}$

1）胆石発生のための 2 つのステップ

（1）コレステロール過飽和胆汁の生成

言うまでもなくコレステロール胆石が発生す るためには，その素材である遊離コレステロー ルが胆汁中で溶存可能となる胆汁酸およびリン 脂質（レシチン）に対して過剩に排出すること が必要であり，これが第一のステップである. 図1のうち 1)にこれら 3 つの成分の間の関係 を示す．三角座表の中の曲線 $\mathrm{ABC}$ の枠外上部 にP点が存在するとコレステロールは過飽和状 態となる．このようなコレステロール過飽和胆 汁はコレステロール胆石患者はもとより肥満, 高脂血症, 糖尿病, 妊娠などの胆汁でしばしば 
表 1.ヒト胆汁より抽出された nucleation 関与物質 anti-nucleating proteins (抑制因子)

\begin{tabular}{|c|c|c|c|}
\hline apolipoprotein A-I, A-I , C-I & Kibe & 1984 & Science \\
\hline phospholipase A2 (in vitro) & Groen & 1989 & Biochem Biophys Acta \\
\hline helix pomatia bound glycoproteins & Busch & 1991 & J Lipid Res \\
\hline$\Gamma^{:}$other glycoproteins & Ohya & 1993 & Gastroenterology \\
\hline$L: \operatorname{IgA}$ & Busch & 1988 & Gastroenterology \\
\hline \multicolumn{4}{|c|}{ pro-nucleating proteins (促進因子) } \\
\hline mucous glycoproteins & Lee & 1981 & $\mathrm{~J}$ Clin Invest \\
\hline$"$ & Levy & 1985 & Gastroenterology \\
\hline $\begin{array}{l}\text { concanavalin A-binding glycoprotein (CABG) } \\
\text { (nonmucous glycoprotein fraction) }\end{array}$ & Groen & 1989 & J Lipid Res \\
\hline 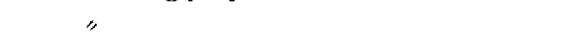 & Harvey & 1989 & Clin Chim Acta \\
\hline$\Gamma^{-}$: phospholipase C & Pattinson & 1991 & Gastroenterology \\
\hline : fibronectin & Chijiwa & 1991 & Biochem Biophys Acta \\
\hline : immunoglobulins & Harvey & 1991 & J Biol Chem \\
\hline$: \operatorname{IgM}, \operatorname{IgG}$ & Upadhya & 1993 & J Biol Chem \\
\hline$\longrightarrow \quad$ : aminopeptidase $\mathrm{N}$ & Nunez & 1993 & FEBS Lett \\
\hline$"$ & Offner & 1994 & Hepatology \\
\hline : a 1-acid glycoprotein & Abei & 1994 & Gastroenterology \\
\hline : haptoglobin & Yamashita & 1995 & J Lipid Res \\
\hline : transferin & Yamashita & 1995 & J Lipid Res \\
\hline L: a 1-antichymotrypsin & Zijlstra & 1996 & Gastroenterology \\
\hline $\begin{array}{l}\text { APF/CBP (anionic polypeptide fraction/ } \\
\text { calcium-binding polypeptide) }\end{array}$ & Ostrow & 1992 & Hepatology \\
\hline phospholipase A2 (in vivo) & Shoda & 1997 & Gastroenterology \\
\hline
\end{tabular}

みられることが知られている。また，高脂血症 薬の一部には同様の作用をもつものもある。こ のような胆汁中の成分を形態的にみると図 2 の ように種々の形の粒子が存在し，一定の方向に 形の変化が続いてゆく（図 2 中矢印の方向）. 胆汁中でコレステロールが過飽和になると，と もすると不足し勝ちな胆汁酸が関与しない粒子 （非ミセル粒子=ベジクル， disc粒子など）を 形成する.

これは胆汁酸が加わっているミセル粒子に比 べて極めて不安定であり，容易にコレステロー ル結晶となり結石へと発育する（図中右上）。

（2）コレステロール結晶の生成（nucleation） 胆汁中で胆汁酸が不足するために，胆汁酸の ないコレステロールとレシチンのみによる非ミ セル粒子は不安定で容易にコレステロール結晶 を析出，胆石となるが，実際にはこれら非ミセ ル粒子には蛋白が結びついていて結晶が現われ
るのに要する速度 (nucleation time) 図 1 の 2) を左右している。この蛋白には幾種類もあり現 在発見されているものの主なものを表 1 に示し ている．表のうち現在のところ食物や薬剤の投 与, つまり外部から増減可能なものはApo蛋白 A-Iとムコ蛋白があげられる。

その他リン脂質を構成している脂肪酸にも同 様にnucleation timeを左右することが明らかに なっている(in vitro). 言うまでもなくこれも 食物によって影響をうける，表1の抑制因子は コレステロール結晶に至る時間を遅らせて胆石 発生を起こりにくくし，逆に促進因子は結晶の 発生を早めて胆石を発生しやすくする。

以上，コレステロール胆石の発生機構につい て述べてきたが，以上のことから考えると胆石 の発生抑制には 2 つの胆石発生機構のステップ である（1）および（2）のうちの発生促進因子 を抑制し，抑制因子を増強すればよいこととな 
表 2. コレステロール胆石形成過程に影響する因子

\begin{tabular}{|c|c|c|c|}
\hline \multicolumn{2}{|l|}{ 胆石促進 } & & 胆石抑妦扴 \\
\hline \multicolumn{2}{|c|}{$\begin{array}{l}\text { 女性，糖尿病，高脂(血症(中性脂肪)， } \\
\text { 娃赈，食事因子(動物脂肪など) }\end{array}$} & 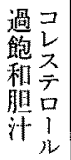 & $\begin{array}{l}\text { ウルソ®(ウルソデオキシコール酸) } \\
\text { ケノデオキシコール酸 } \\
\text { スタチン系高脂血症辈 } \\
\text { リノール酸 }\end{array}$ \\
\hline $\left.\begin{array}{l}\text { リノール酸 } \\
\text { プロスダダランディン } \\
\text { 胆整運動 }\end{array}\right\}$ & $\begin{array}{l}\text { 胆汁粘液 } \\
\text { 睆留 } \\
\left(\begin{array}{c}厶 \text { 蛋白 } \\
\text { 增 加 }\end{array}\right)\end{array}$ & 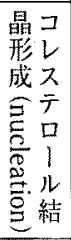 & 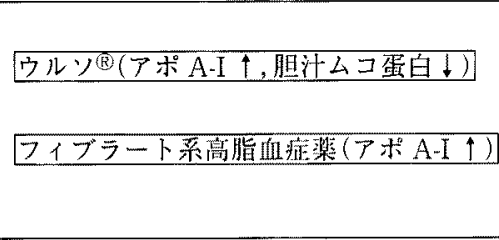 \\
\hline
\end{tabular}

*コレステロール結晶形成 nucleation を左右する物質で薬物や食物により増減を示す ものはアポA-I，ムコ蛋白，リン脂質脂肪酸(リノール酸)の3つが見付かっている.

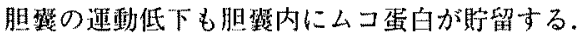

る.

\section{2）発生および抑制因子}

表 2 はこの考え方に基づいて，胆石発生と抑 制に関与する因子の主なものについてまとめた ものである。

以下，これらの因子のうち教室で得だ成績に 基づいて述べることとする。

\section{（1）高脂血症薬の影響}

1975年Grundyらはクロフィブラート (CPIB) には胆汁コレステロールを増加きせ胆石の発生 を促すことを報告しだ．現在市販中のフィブ ラート系のものに同様の傾向を示すものもある が8)，スタチン系の高脂血症薬には過剩の胆汁 コレステロールを抑制するものもあり，それぞ れ薬剤の性質を知っておく必要がある ${ }^{9 !}$ 。 た，フィブラートには血清Apo A-Iを増加させ る効果も同時にあり，このことは後に示す UDCA (ursodeoxycholic acid) と同様に胆汁 Apo A-Iも増加させる可能性がある.

（2）リン脂質を構成する脂肪酸の影䜾

胆汁脂質粒子はいずれにも共通してリン脂質 (レシチン) が加わっており，その親水部分が コレステロールを胆汁中で溶存可能としてい る.われわれの実験ではこの脂肪酸の種類に よってdisc粒子や心゙ジクルの安定性に差のある ことが明らかとなってきだ゚.
(O.D.)

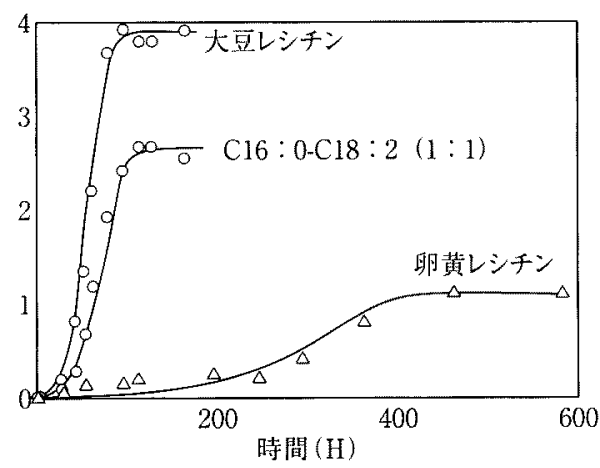

困 3.レシチン脂肪酸の㮔類によるnucleation timeの 違い

図 3 は人工胆汁中で析出してくるコレステ ロール結晶を経時的に定量したもの（O.Dで表 現したもの）である（nucleation time簡便測定 法)。図中SB-L（大豆レシチン）とEY-L（卵黄 レシチン）で構成されたものを比較すると明ら かに差があり，卵黄レシチンではゆっくりとコ レステロール結晶が析出してくる。これに対し て大豆レシチンでは極めて短時間で結晶が析出 し, 不安定な胆汁脂質粒子で構成されているこ とが解る。このことは電子影微鏡下で観察する こともでき，卵黄レシチンではベジクルが漱次 肥大しコレステロール結晶が析出している像が 観察されているが，大豆レシチンでは針状結晶 が現われ，コイル状となり連なった結晶が現わ 
れ，通常とは異なった結晶析出経過を示す．以 上の成績は食物脂肪が胆石発生機序のステップ の（2）つまり nucleationに影響することを指 摘するものである.

（3）UDCA (ursodeoxychol酸) の影響

UDCAはすでに約20年前より, CDCA（chenodeoxychol酸）と共に胆石溶解薬として用い られてきた．従って予防的にも当然効果をもっ ており, 欧米では肥満の治療時に 3 割とも言わ れている胆石の発生の予防に用いられている.

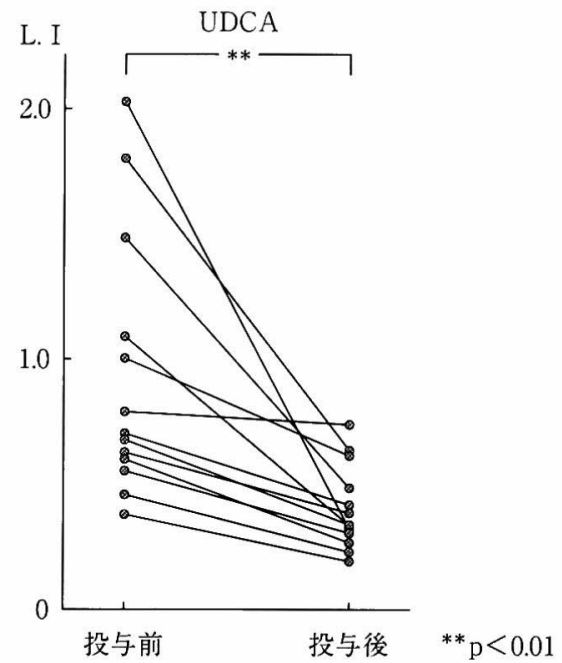

図 4.5 力月UDCA投与後の胆石形成指数の変化

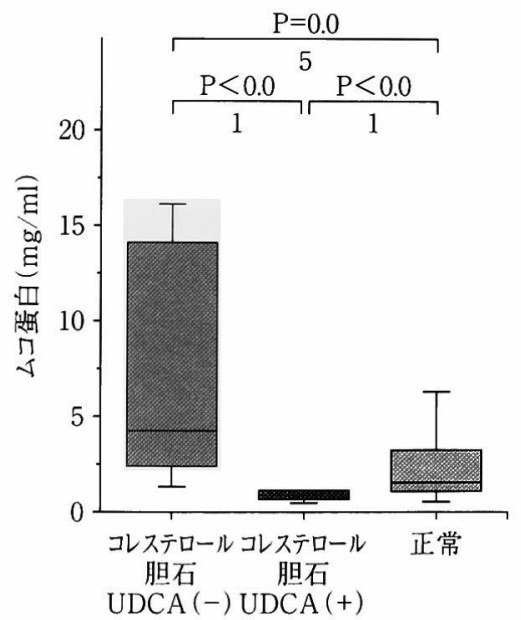

UDCAの胆石抑制機序はCDCA と同様に胆石発 生機序のステップの（1）つまりコレステロー ル過飽和汁の抑制にあると考えられてきた。三 角座表のP点の位置から計算するとUDCAを投 与することで明らかに胆石形成能は低下する (図 4).

しかし, その後の研究でUDCAはCDCAと 違ってミセルの形成能力は充分ではなく計算通 りの結果とはなり得ないことがわかってきて, ステップ（1）の過飽和胆汁に対する抑制効果 では十分な説明ができ得なかった.われわれは, このことからUDCAのステップ（2）に対する

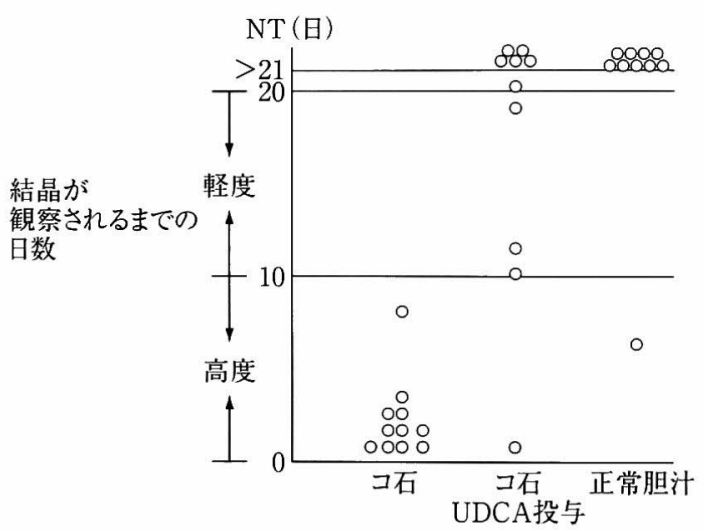

図 5. Nucleation timeに対するUDCAの効果 コ石：コレステロール結石

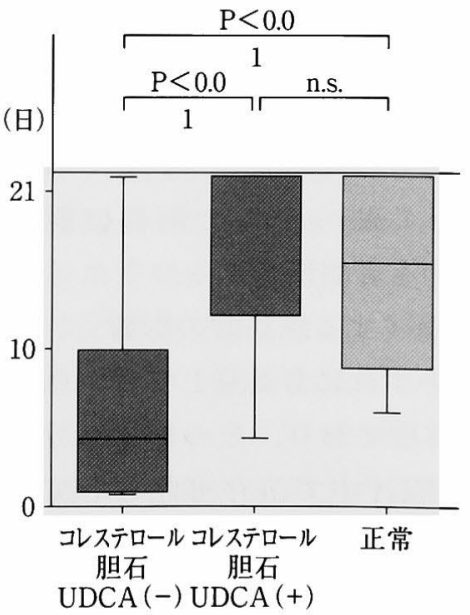

図 6.UDCA投与による胆褧胆汁中のムコ蛋白浱度と nucleation timeの変化 


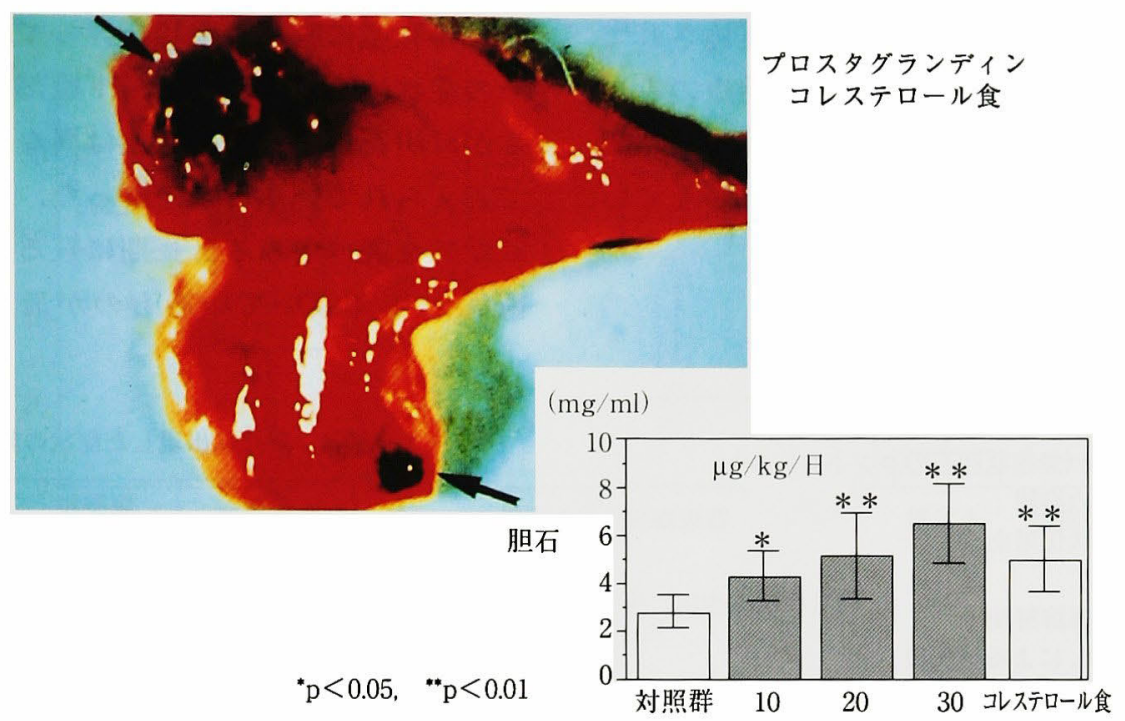

図 7.プロスタグランディン $\mathrm{E}_{2}$ 投与による胆麗ムコ蛋白の増加

効果についての検討を長年にわたり行ってきた が, UDCAには血清中のApo A-Iを増加させる 現象がみられ，それと同時に胆汁中のnucleationを遅らせるステップ（2）への影響（図 5 ） を観察することができた ${ }^{11)}$.つまりUDCAの胆 石卯制効果はステップ（1）の効果を否定でき ないものの，ステップ（2）の効果によるとこ ろが大きいことが明らかとなったそそのほか Apo A-Iは胆汁のdisc粒子と共に行動する.血 清中で増加したApo A-Iはその増加に応じて胆 汁中でも増加する. 実際にApo A-Iが胆汁中で 胆汁脂質粒子を安定化させ，コレステロール結 晶に至るのを遅らせる状態を電顕下で観察する ことができた。このようにUDCAの胆石抑制効 果はApo A-Iを通してステップ（2）との係わ りが極めて大きいことが次々と明らかになっ た.

更にUDCA投与は胆汁で胆石の発育に促進作 用をもつムコ蛋白を著明に抑制し，その結果nucleationを延長する効果をもつことも明らかに することができた (図6 $)^{12)}$.
（4）プロスタグランディンのムコ蛋白に対す る効果

プロスタグランディン E2 は胃粘膜のムコ蛋 白を増加させ粘膜の保護に有用性を発揮する。 同様の効果は胆褧粘膜でも起こり ${ }^{13)}, 么 コ$ 蛋白 は増加する (動物実験)。このことは胆石の発 育に促進的に働く可能性が大きい（図 7 ).

胆䨢の収縮運動が低下すると濃縮を続ける胆 囊中でムコ蛋白は増加し胆石の発育に寄与する ことになる. 反対に前述のUDCAはこの粘膜の 量を減少させることにより胆石を抑制する.

3）胆石の予防の概念と対策

以上の如く, 胆石の発生過程には 2 つのス テップの胆汁生化学的変化が大きく関与する. 胆石の溶解治療や体外衝撃波治療中，あるいは 表 3 に揚げるような予防に際してはこの 2 つの ステップの中の胆石抑制因子を増強させ, 且つ 促進因子を可及的に除去する必要がある．胆石 の予防とは一から三次予防に分けて考えること ができる．表の 3)のii）を除くと，すべてコレ ステロール胆石はその発生機構に関与する因子 を抑えることにより防ぐことができる．古くか らコレステロール胆石の多かった欧米ではこう 
した考え方は概念としてとらえられ実施されて きたが，わが国では発生した胆石の治療のみに 主眼がおかれ，しかも最近では腹腔鏡による胆 囊摘出という外科治療が再び主体となってい る.

表 3. 胆石の子防

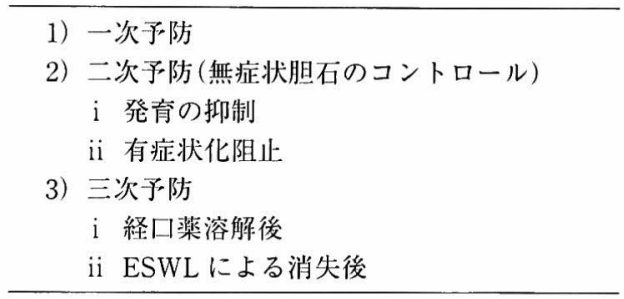

ESWL : 体外衝撃波砤石術

\section{2. 胆囊摘出と胃病変}

最近の胆道造影法や外科手技の向上によって いわゆる胆褧摘出後症候群は減った。 しかし術 後の経過を長期にわたり観察すると, 開腹手術 によるものについても, 腹腔鏡的胆囊摘出術で
も15\%程度に腹部の症状を伴っており（表 4)， その症状は心窩部, 背部, 下腹部の疼痛ではあ るが, 胆石手術前の症状とは異なった感触とし て訴えられていることが解った。この症状の持 続期間を調べてみると長期に亘るものが多く, 術後 $2 \sim 5$ 年続いているものが最も多く, 10年

表 4. 新たに出現した症状の頻度

\begin{tabular}{l|rl|c}
\hline & $\begin{array}{c}\text { 手術 } \\
\mathrm{n}=255\end{array}$ & $\begin{array}{c}\text { 腹腔鏡 } \\
\mathrm{n}=617\end{array}$ & $\begin{array}{c}\text { 合計 } \\
\mathrm{n}=872\end{array}$ \\
\hline 腹がはる & $9(3.5)$ & $29(4.7)$ & $38(4.4)$ \\
腹が重い & $2(0.8)$ & $15(2.4)$ & $17(1.9)$ \\
吐き気 & $4(1.6)$ & $20(3.2)$ & $24(2.8)$ \\
食欲不振 & $5(2.0)$ & $11(1.8)$ & $16(1.8)$ \\
胃部痛 & $4(1.6)$ & $33(5.3)$ & $37(4.2)$ \\
背部痛 & $12(4.7)$ & $35(5.7)$ & $47(5.4)$ \\
下腹部痛 & $13(5.1)$ & $20(3.2)$ & $33(3.8)$ \\
胸焼け & $4(1.6)$ & $24(3.9)$ & $28(3.2)$ \\
体重減少 & $6(2.4)$ & $14(2.3)$ & $20(2.3)$ \\
げっぷ & $3(1.2)$ & $19(3.1)$ & $22(2.5)$ \\
下痢 & $17(6.7)$ & $71(12.0)$ & $88(10.1)$ \\
便秘 & $21(8.2)$ & $37(6.0)$ & $58(6.7)$ \\
その他 & $14(5.5)$ & $59(9.6)$ & $73(8.4)$ \\
\hline \multicolumn{3}{r}{}
\end{tabular}

一簡便、非侵襲的手技-
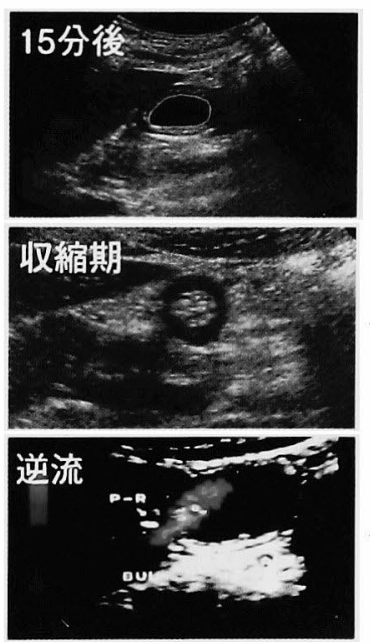

十二指腸胃逆流

胃排出能

前庭部運動能
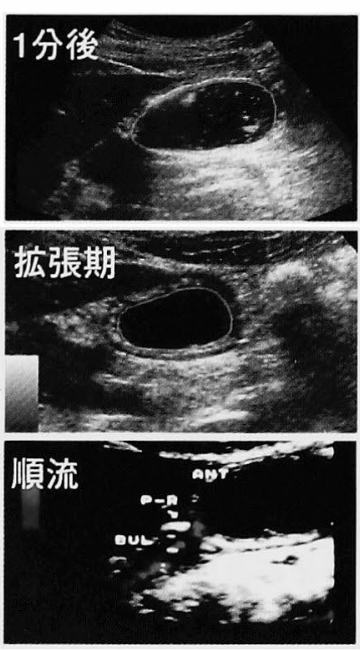

図 8 .

胃排出能：試験食投与後一定時間内の胃の断面積の差より算出 前庭部運動能：前庭部の最大断面と最小断面の差より算出 十二指腸胃逆流：ドプラー効果により流れの方向を検知 青が順流 赤が近流（教室で開発した胃運動の非侵襲的測定法） 

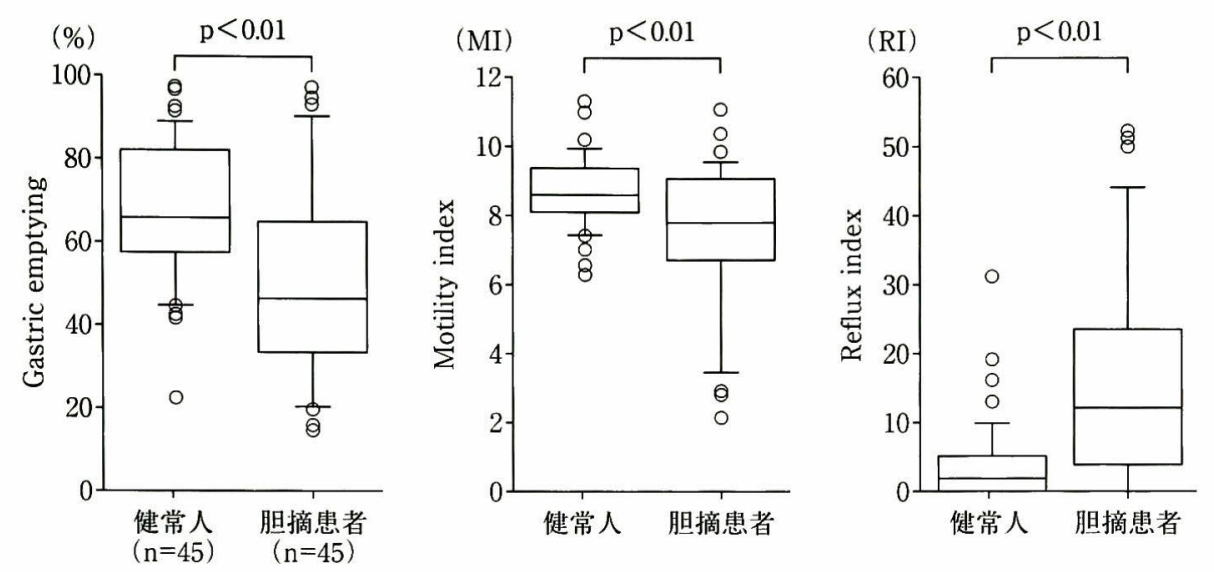

図 9．健常人と胆摘患者の胃十二指腸運動の比較
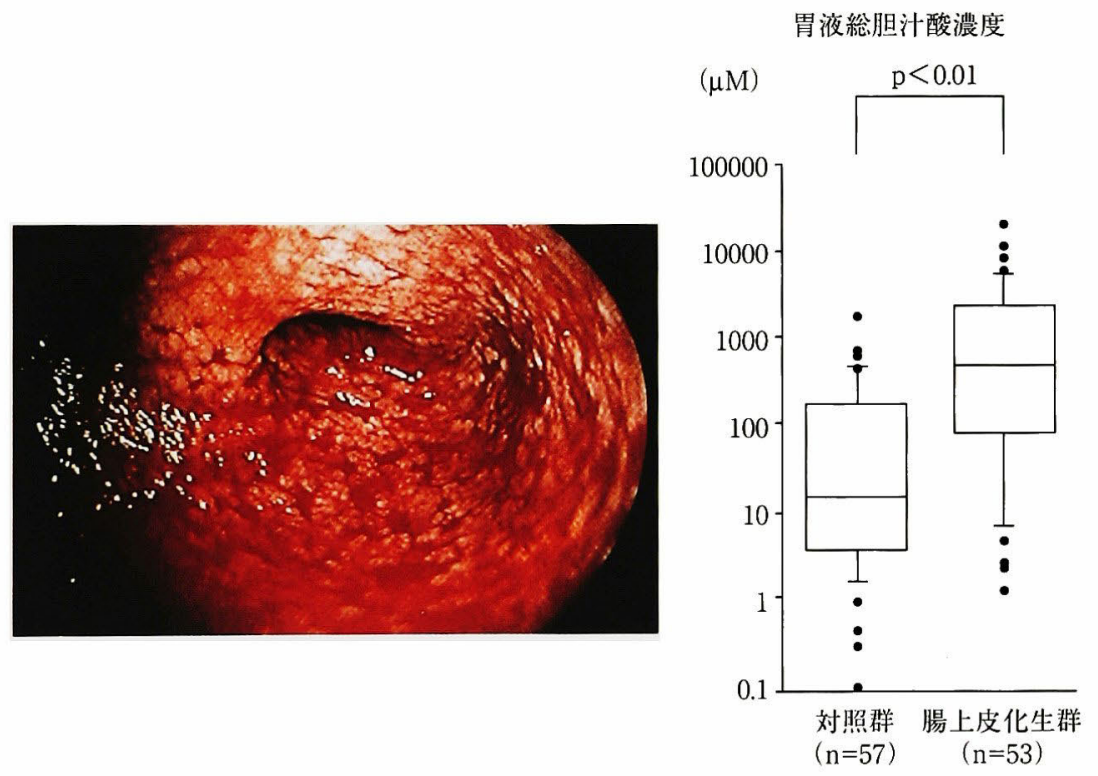

図10．胃内胆汁酸の增加は，腸上皮化生を進展させる

に及ぶものもあった．

このような症状の原因について教室では腹部 超音波を用いて調べた．本法によると胃の排出 能, 運動能, 十二指腸一胃逆流能を測定するこ とができる $(\text { 図 } 8)^{14)}$ 。この方法によって胆囊 摘出後の患者についてこれらの胃機能を調べた ところ, 排出能や運動能には異常が少なかった が，十二指腸一胃逆流には明らかに強い異常が みられ, 逆流の増強がみられた（図 9 ). 更に
イヌを使って胆囊摘出後の病態を調べたとこ ろ, 幽門の弛緩する頻度が明らかに増大するこ とが観察された。このことから胆囊摘出は幽門 筋の機能に変化を与え, 十二指腸液の胃内逆流 を促すことがわかる. しかも, 症状の明らかな 例では逆流した十二指腸液の胆汁成分のうち dihydeoxy胆汁酸 (deoxychol酸やchenodeoxychol酸）の割合が多く, 胃粘膜障害性の傾向が 強い胆汁酸の割合が多いことが解った。このこ 

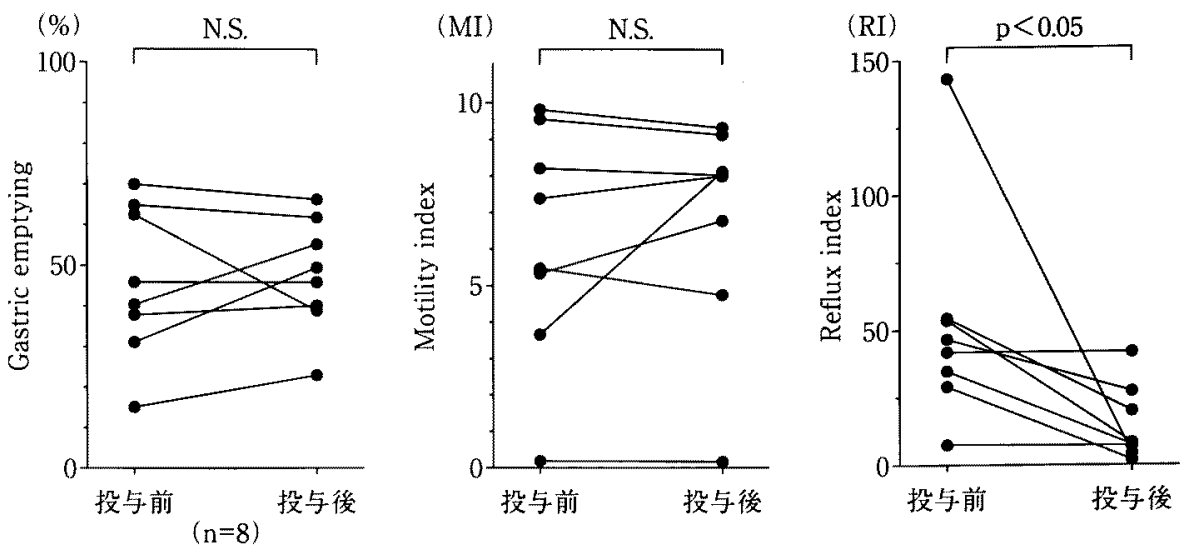

図11。胆摘患者のトリメブチン投与前後の胃十二指腸運動の比較

N.S：有意差なし

とからわれわれはこの病態をpostcholecystectomy dyspepsiaと呼ぶことを提唱したい.

年余に亘石胆汁酸の胃内逆流は萎縮のpromotorになり得ると考えられる．長期に亘る胆 褧摘出患者の中には粘膜の広範な腸上皮化生を 来している例も多く，このような腸上皮化生の なかには癌に発展する例も少なくない(図10). こうした逆流による症状を有する患者に消化管 運動機能改善薬 (trimebutine maleate) ${ }^{15}$ を投 与することにより，逆流する十二指腸液の量が 減少し，同時に症状が改善した（図11）。

\section{おわりに}

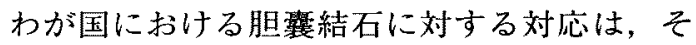
の絶対的多数ができ上がった結石を胆翼と共に 切除する方法に頼っている。近年, 腹腔鏡的胆 翼摘出術が拡がり，その傾向は一層強くなって いることも周知の通りである. しかし胆裹の頳 失は決して生理的なものではなく，十二指腸一 胃逆流による胃粘膜の萎縮へ進展する可能性を もって扔り，長期的にみると癌化することを考 慮する必要がある. 予防可能であり, 胆缼温存 治療可能なコレステロール胆石が増加したわが 国では長期的にみて，胆慗を切除することのみ に力点をおいた現在の治療法を再考する必要が
あることを示した。

\section{文献}

1）谷村 弘, 他: 全国胆石症1996年度調查結果報告. 胆 道 $11: 133-140,1997$.

2) Grundy SM, et al : Highlights of the meeting on prevention of gallstones. Hepatology $7: 946-951.1987$.

3) Hoffman AF : Primary and secondary privention of gallstone disease: Implications for patients managememt and research priorities. Am J Surgery 165:541-548. 1993.

4）田妻 進, 他：特集 無症状胆石と有症状胆石の無症 状化に関する䠦床的検討一胆裹温存潦法の位置付けに 関して一. 胆と膵 $19: 303-308 ， 1998$.

5）花の木睦巳, 他：胆襄摘出の胃十二指腸運動に及ほす 影響. 消化器科 $23: 535-541,1996$.

6) Small DM:Cholesterol nucleation and growth in gallstone formation [editorial]. N Engl J Med 302:13051307, 1980.

7) The coronary drug project research group: Clofibrate and niacin in coronary heart disease. JAMA $231: 360-$ 381. 1975.

8）梶山梧朗,他：13F-759胆汁脂質に与える影響について。 臨床医薬 $4: 2343-2355,1988$.

9) 田妻 進, 他：高脂血症薬CI-981 (Atrovastatin) の 胆汁脂質に与文る影響の検討。臨床医薬 $14: 2163$ $7177,1998$.

10) Ochi $\mathrm{H}$, el al:Lecithin hydrophobicity modulates the process of cholesterol crystal nucleation and growth in supersaturated model bile systems. Biochem J 318: 139-144. 1996.

11) Tazuma $S$, et al : Effect of ursodeoxycholic acid admini- 
stration on nucleation time in human gallbladder bile. Gastroenterology 97 : 173-178, 1989 Jul.

12) Tazuma $S$, et al: The role of bile acid in extracorporeal shock wave lithotripsy (ESWL) of gallstone patients. In Shock Waves, vol 2:ed. by Takayama, p1201-1204, 1991. Springer-Verlag.

13) Sasaki H, et al : Effects of 16, 16-dimethyl prostaglandin E2 on biliary mucous glycoprotein and gallstone formation in guinea pigs. Scand J Gastroenterol $28: 495-499$,
1993.

14）花の木睦巳，他：体外式超音波法による胆石症拉よび 胆罴摘出後患者の胃十二脂腸運動機能, 特に十二脂腸 胃逆流の棓価. Therapeutic Research 17:3991-3994, 1966.

15）花の木㓐巳，他：胃十二脂腸運動異常に由来する胆摘 出後dyspepsia症状に対するtrimebutine maleateの効果 体外式超音波検查法に上る検討臨床と研究 $73: 2139-$ 2142, 1996. 